\title{
Streamflow Response to Climate and Landuse Changes in a Coastal Watershed in North Carolina
}

\author{
S. Qi, G. Sun, Y. Wang, S. G. McNulty, J. A. Moore Myers
}

\begin{abstract}
It is essential to examine the sensitivity of hydrologic responses to climate and landuse change across different physiographic regions in order to formulate sound water management policies for local response to projected global change. This study used the U.S. Geological Survey's Precipitation Runoff Modeling System (PRMS) model to examine the potential impacts of climate and landuse changes on the monthly streamflow of the Trent River basin on the lower coastal plain of eastern North Carolina. The model was first calibrated and then validated using measured, historic, long-term daily streamflow. The model performed satisfactorily for simulating monthly streamflow, as indicated by an overall Nash-Sutcliffe simulation efficiency greater than 0.85. We examined the sensitivity of streamflow to changes in air temperature and precipitation. The simulations suggested that streamflow of individual years could change from $-93 \%$ to $238 \%$, depending on the two global circulation model (GCM) scenarios used (i.e., HadCMSul2 and CGC1). Streamflow of the Trent River will decrease with an increase in air temperature, and increase (or decrease) with an increase (or decrease) in precipitation. Streamflow was more sensitive to prescribed changes in precipitation than to air temperature for the study area, given its high and stable evapotranspiration rates in the humid climatic environment. Seven hypothetical landuse change scenarios representing forest conversion to crop lands and urban areas indicated that water yield could increase by $14 \%$ to $20 \%$. The likely impacts of landuse changes may not be as high as those caused by predicted changes in climate, but moderate urbanization and extreme hydrologic events caused by climate change could pose significant water quantity and quality problems in the Trent River basin.
\end{abstract}

Keywords. Climate change, Landuse change, PRMS, Watershed streamflow North Carolina.

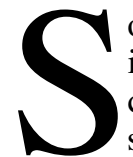

ocietal demands for water have increased due to rapid population growth, water pollution, and climate change across the U.S. (Postel et al., 1996). The southeastern U.S. will experience a likely $40 \%$ increase in population on average between 2000 and 2025, with much of the growth being on the coastal region (NPA Data Services, Inc., 1999). This rapid increase in population and associated landuse change (Wear and Greis, 2002) and water degradation will further stress the water resources and ecosystems in the coastal zones. Climate change and climate variability due to global warming add new dimensions to modern water resource management, as climate change may further stress water availability for human and natural ecosystems at a large scale (National Assessment Synthesis Team, 2000). Seasonal droughts that have occurred in North Carolina and around the southeastern U.S. in the past several years have exposed the vulnerability of the public water sup-

Submitted for review in April 2008 as manuscript number SW 7460; approved for publication by the Soil \& Water Division of ASABE in April 2009.

The authors are Shi Qi, Associate Professor, College of Soil and Water Conservation, Beijing Forestry University, Beijing, China; Ge Sun, Research Hydrologist, Southern Global Change Program, USDA Forest Service, Raleigh, North Carolina; Yunqi Wang, Associate Professor, College of Soil and Water Conservation, Beijing Forestry University, Beijing, China; Steven G. McNulty, Project Leader, and Jennifer A. Moore Myers, Resource Information Specialist, Southern Global Change Program, USDA Forest Service, Raleigh, North Carolina. Corresponding author: Ge Sun, Southern Global Change Program, USDA Forest Service, 920 Main Campus Drive, Suite 300, Raleigh, NC 27606; phone: 919-515-9498; fax: 919-513-2978; e-mail: ge_sun@ncsu.edu. ply to climate variability and ever-increasing water demand in a traditionally "water-rich" region. Quantifying streamflow response to potential impacts of climate change and variability is the first step to developing long-term water resource management plans.

Landuse change alters the hydrologic cycles by affecting ecosystem evapotranspiration, soil infiltration capacity, and surface and subsurface flow regime (Skaggs et al., 2006; Sun et al., 2004). Empirical manipulation studies on the effects of landuse and climate changes on water resources have been limited at the watershed scale (Rose and Peters, 2001). Experiments and data analyses have been rarely done for large basins. Since it is not feasible to conduct vegetation manipulation studies for large basins, hydrologists often use routine monitoring data to detect hydrologic changes due to historic landcover changes (Trimble and Weirich, 1987). During the past century, the effects of deforestation and reforestation on watershed hydrology have been well studied around the world (Andreassian, 2004; Brown et al., 2005), in the southeastern U.S. (Sun et al., 2001, 2004; Jackson et al., 2004), and in North Carolina (Swank et al., 2001; Skaggs et al., 2006). Such studies used a "paired watershed" approach or analyzed long-term hydrologic data for a single watershed that experienced landcover and landuse change (Bosch and Sheridan, 2006). Overall, past studies suggest that the magnitude of hydrologic response to landcover change varies with climate, geology, soil, and vegetation growth status (e.g., vigor, age) (Chang, 2002; Barlage et al., 2002; Brian et al., 2004). Future watershed hydrologic changes due to land conversion are expected to be site-specific, and climate variability is an important factor controlling basin hydrologic processes. 
Climate change is about hydrologic change. Climate change and variability have both direct and indirect effects on the hydrologic cycle at multiple scales by altering the physical and biological processes of ecosystems (McNulty et al., 1997). Climate change directly affects precipitation amount and intensity and potential evapotranspiration (Calder et al., 1995). It indirectly affects plant water use efficiency, and therefore total evapotranspiration, through altering plant growth rate and species composition.

Hydrologic models provide a framework for examining the complex effects of both climate and landuse changes on watershed hydrology (Leavesley, 1994; Amatya et al., 1997; Arnold et al., 1998; Legesse et al., 2003; Xu, 2000; Arnold and Fohrer, 2005). Physically based, distributed models that represent the spatial variability of land surface and climatic characteristics are most useful for examining the hydrologic effects of landuse change and climate variability for large basins (Andersen et al., 2001; Borah and Bera, 2003). Computer modeling is perhaps the only means by which to study the individual and combined impacts of multiple factors on watershed hydrology for large regions (Refsgaard, 1987; Lorup et al., 1998; Rosenberg et al., 1999). Simulation models are available to begin to address climate change issues in the southeast at the watershed to regional scales. Climate change impact studies have been conducted at the national scale (Wolock and McCabe, 1999; Rosenberg et al., 2003), across the southeastern region (McNulty et al., 1997; Sun et al., 2008), and for a large watershed scale (Nash and Gleick, 1991). For example, Stone et al. (2001) used the SWAT model (Arnold et al., 1998), coupled with a regional climate model to examine how doubling atmospheric $\mathrm{CO}_{2}$ affects water yield for the Missouri River basin. They found that climate change increased water yield in the fall and winter months but decreased it by $10 \%$ to $20 \%$ during spring and summer months. Similarly, using the SWAT model and six different climate change models, Jha et al. (2006) concluded that the Upper Mississippi River Basin was very sensitive to forecasted future climate change scenarios.

In contrast, few studies have been performed for the southeastern region. McNulty et al. (1997) and Sun et al. (2000) conducted several hydrologic impact studies at the watershed to regional scale across the southern U.S., in which $55 \%$ of the land mass is covered by forests, using the forest ecosystem model PnET. They found that climate warming would increase forest evapotranspiration as forest growth increases, but overall water yield was expected to follow the trends of projected precipitation patterns. Liang et al. (2002) applied a modified forest ecosystem model, PnET-3SL, to the southern U.S. and found that the model adequately predicted monthly streamflow for over 30 watersheds with diverse physiographic characteristics. Using the DRAINMOD model, Amatya et al. (2006) examined climate change impacts on drainage and shallow groundwater table levels in a large, drained loblolly pine plantation on the lower coastal plain of eastern North Carolina. The study concluded that climate change effects on drainage patterns are largely dependent on changes in precipitation. Shallow groundwater depth may be lowered due to increased evapotranspiration and/or decreased precipitation, but soil moisture was not affected sufficiently to limit tree growth (Amatya et al., 2006). Similarly, using the MIKE SHE model, Lu et al. (2006) predicted that climate warming would lower groundwater table levels in forested wetlands in the southeastern U.S., especially during dry seasons when changes in shallow groundwater tables are the largest.

The overall goal of this study was to examine how climate and landuse changes affect streamflow in coastal North Carolina. The specific objectives of the study were to: (1) test the U.S. Geological Survey's Precipitation Runoff Modeling System (PRMS) for modeling streamflow of the Trent River, a large basin on the coastal plain of North Carolina, and (2) perform a hydrologic sensitivity assessment and quantify the magnitudes of hydrologic response to possible climate and landuse changes for the Trent River basin.

\section{Methodology}

\section{WATershed Hydrologic Model}

The U.S. Geological Survey's Precipitation Runoff Modeling System (PRMS), which is embedded in the Modular Modeling System (MMS), was selected for this study (Leavesley et al., 1983, 2002). This model has been widely used to model the streamflow of large basins with mixed landuses (Hay et al., 2006; Jha et al., 2006). PRMS is a modulardesign, deterministic, distributed-parameter, watershed modeling system (Leavesley et al., 1983). The model simulates basin response to normal and extreme rainfall and snowmelt and can be used to evaluate changes in water-balance relationships, flow regimes, flood peaks and volumes, soilwater relationships, and groundwater recharge. Parameter optimization and sensitivity analysis capabilities are also provided, allowing for optimization of model parameters and evaluation of individual and joint effects on model outputs (Leavesley et al., 1983, 2002).

PRMS divides a watershed into smaller modeling subunits based on its physical characteristics of slope, aspect, elevation, vegetation type, soil type, landuse, and precipitation distribution. Two levels of partitioning are available; the first divides the basin into homogeneous hydrologic response units (HRU) based on the basin characteristics. Water balances are computed daily, and energy balance is computed twice each day for each HRU. The sum of the responses of all HRUs, weighted on a unit-area basis, produces the daily system response and streamflow for the basin. A second level of partitioning is available for storm hydrograph simulation, in which the watershed is conceptualized as a series of interconnected flow planes and channel segments. Surface runoff is routed over the flow planes into the channel segments, and channel flow is routed through the watershed channel system. An HRU can be considered the equivalent of one flow plane, or it can be delineated into a number of flow planes. In this study, the daily mode was used for modeling daily total and monthly streamflow.

\section{Trent River Basin Description}

The Trent River basin $\left(35.37^{\circ} \mathrm{N},-77.55^{\circ} \mathrm{W}\right)$, a tributary of the Neuse River, is located in eastern North Carolina's lower coastal plain geographic region, situated within the warm and humid southeastern U.S. (fig. 1). The total drainage area is $377 \mathrm{~km} 2$ based on a $30 \mathrm{~m}$ resolution digital elevation model (DEM). The river has an average channel slope of $0.51 \mathrm{~m} / \mathrm{km}$, stream length of $49.2 \mathrm{~km}$, mean basin elevation of $30 \mathrm{~m}$ (7 to $50 \mathrm{~m}$; referenced to NGVD29), and a mean topographic relief less than $2 \%$ (table 1). Dominant soils are poorly drained sand and loam derived from marine sediments. Landuse is domi- 


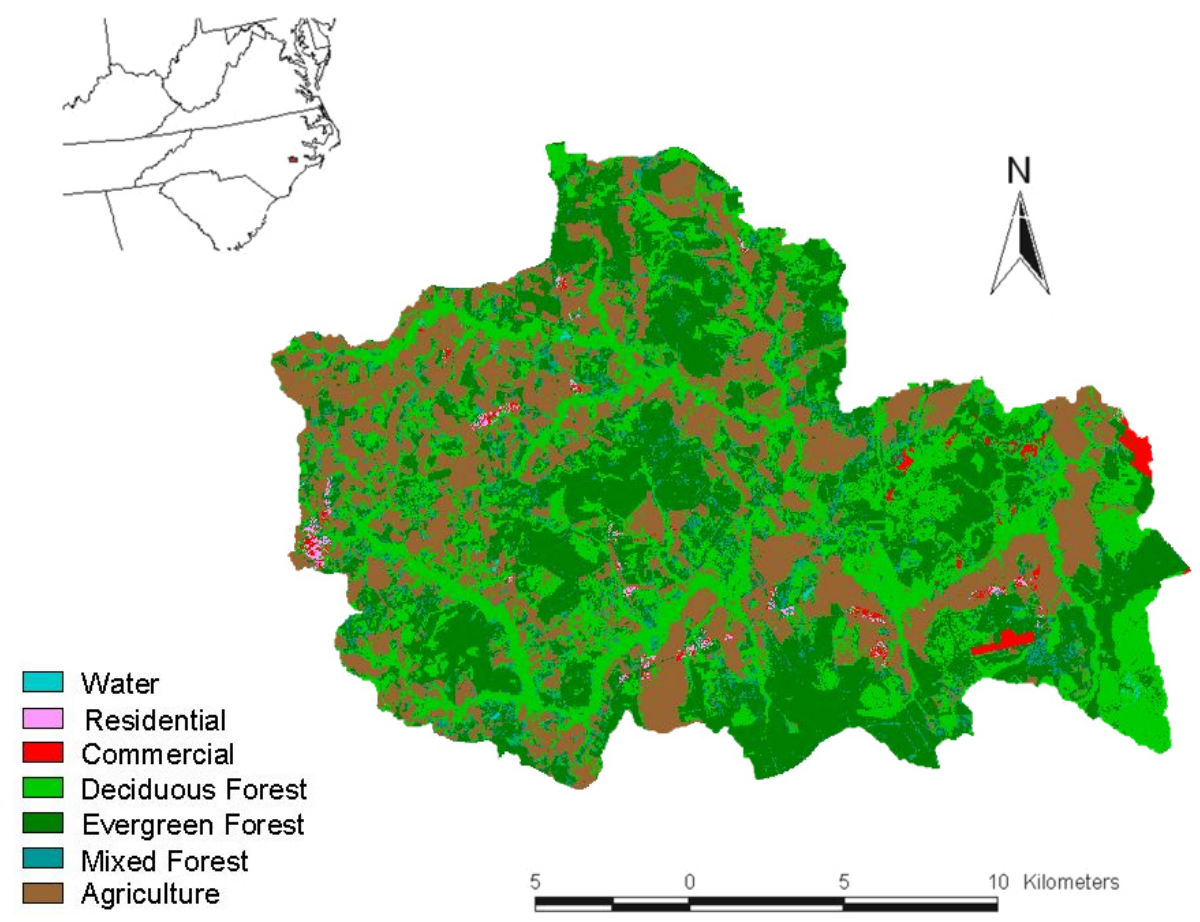

Figure 1. Location and topography of the Trent River basin.

Table 1. Key characteristics of each HRUs for the Trent River Basin.

\begin{tabular}{ccccc}
\hline $\begin{array}{c}\text { HRU } \\
\text { No. }\end{array}$ & $\begin{array}{c}\text { Mean } \\
\text { Elevation } \\
(\mathrm{m})\end{array}$ & $\begin{array}{c}\text { Mean } \\
\text { Slope }\end{array}$ & $\begin{array}{c}\text { Soil } \\
\text { Type }\end{array}$ & $\begin{array}{c}\text { Maximum Soil } \\
\text { Water Storage } \\
\text { Capacity }(\mathrm{mm})\end{array}$ \\
\hline 1 & 25 & 0.0076 & 1 & 51 \\
2 & 33 & 0.0122 & 1 & 20 \\
3 & 21 & 0.0069 & 1 & 20 \\
4 & 14 & 0.0051 & 2 & 91 \\
5 & 16 & 0.0076 & 2 & 91 \\
6 & 34 & 0.0151 & 2 & 91 \\
7 & 24 & 0.0153 & 2 & 91 \\
8 & 14 & 0.0049 & 2 & 91 \\
9 & 17 & 0.0053 & 1 & 51 \\
10 & 21 & 0.011 & 1 & 91 \\
11 & 34 & 0.0142 & 2 & 91 \\
12 & 26 & 0.0103 & 2 & 91 \\
13 & 17 & 0.0095 & 2 & 91 \\
14 & 20 & 0.0075 & 2 & 91 \\
15 & 20 & 0.0055 & 2 & 91 \\
16 & 17 & 0.003 & 2 & 91 \\
17 & 20 & 0.011 & 2 & 91 \\
18 & 18 & 0.0071 & 1 & 51 \\
19 & 24 & 0.0105 & 1 & 51 \\
20 & 22 & 0.0051 & 1 & 51 \\
21 & 22 & 0.0038 & 1 & 51 \\
22 & 34 & 0.0149 & 1 & 20 \\
\hline
\end{tabular}

nated by deciduous and conifer forests and croplands, representing about $70 \%$ and $29 \%$ of the total basin area, respectively. The climate in the study region is hot and humid in the summer, and cool in the winter with occasional brief cold spells. Rains occur throughout the year and are fairly heavy; rainfall pattern are affected by hurricanes in the summer and fall. The Kinston weather station (www.nc-climate.ncsu.edu/ cronos/normals.php?station $=314684$ ) recorded a long-term (1970-2000) mean daily temperature of $15.8^{\circ} \mathrm{C}$ and mean annual rainfall of approximately $1300 \mathrm{~mm}$.

\section{Databases}

Daily maximum and minimum air temperature and daily precipitation data (1980-2001) were acquired from the State Climate Office of North Carolina (the Trent River has one gauge station). Total daily streamflow data (1980-2001) and watershed topography in the form of DEMs were acquired from the U.S. Geological Survey. Landcover data were derived from U.S. Geological Survey $1 \mathrm{~km}$ gridded landuse and landcover data (Anderson et al., 1976), while $1 \mathrm{~km}$ vegetation type and density data were derived from U.S. Forest Service vegetation maps (USDA, 1992). Soil physical parameters were obtained from the $1 \mathrm{~km}$ gridded State Soil Geographic Database (STATSGO; USDA, 1994). Two primary global circulation models (GCMs), one developed at the Canadian Climate Centre (CGC1) and one at the Hadley Centre (HadCMSul2), were used as inputs to examine the long-term hydrologic effects of climate change on the Trent River basin. Both climate change scenarios were products of the Vegetation/Ecosystem Modeling and Analysis Project (VEMAP), with spatial resolution of 0.5 by 0.5 degrees (about $50 \mathrm{~km}$ ) (Kittel et al., 1997). Both models predict a warming trend by the end of the 21st century, with at least a $4^{\circ} \mathrm{C}$ increase over most of the North American continent in all seasons. CGC1 predicts that much of Canada and the U.S. will see a strong change in winter temperature by $9^{\circ} \mathrm{C}$ warmer. Predicted winter temperature increases by the HadCMSul 2 model are modest but still reach $1^{\circ} \mathrm{C}$ to $5^{\circ} \mathrm{C}$ across the U.S. in all seasons (National Assessment Synthesis Team, 2000). We used the predicted climate data (precipitation and air temperature) for the area that overlays the Trent River basin.

\section{HRU Delineation and Key Model Parameters}

HRU delineation and characterization, and initial model input parameters were generated using the GIS interface GIS Weasel (Viger et al., 1998; www.brr.cr.usgs.gov/weasel). 
Table 2. Average coefficient of model-fit efficiency $(E)$ and relative error $(E r)$ for the calibration and validation periods.

\begin{tabular}{|c|c|c|c|c|c|c|c|c|}
\hline & \multicolumn{4}{|c|}{ Daily Fit-Efficiency/Relative Error } & \multicolumn{4}{|c|}{ Monthly Fit-Efficiency/Relative Error } \\
\hline & 22 HRUs & 71 HRUs & 118 HRUs & 225 HRUs & 22 HRUs & 71 HRUs & 118 HRUs & 225 HRUs \\
\hline $\begin{array}{c}\text { Calibration } \\
\text { (1993-2001 water year) }\end{array}$ & $0.63 / 54$ & $0.64 / 52$ & $0.54 / 53$ & $0.52 / 53$ & $0.88 / 31$ & $0.91 / 27$ & $0.89 / 29$ & $0.91 / 27$ \\
\hline $\begin{array}{c}\text { Validation } \\
\text { (1981-1991 water year) }\end{array}$ & $0.49 / 63$ & $0.50 / 56$ & $0.51 / 55$ & $0.49 / 56$ & $0.58 / 46$ & $0.71 / 37$ & $0.71 / 37$ & $0.71 / 37$ \\
\hline $\begin{array}{c}\text { Overall } \\
(1981-2001 \text { water year) }\end{array}$ & $0.58 / 56$ & $0.53 / 54$ & $0.53 / 54$ & $0.51 / 54$ & $0.79 / 38$ & $0.76 / 32$ & $0.75 / 33$ & $0.75 / 33$ \\
\hline
\end{tabular}

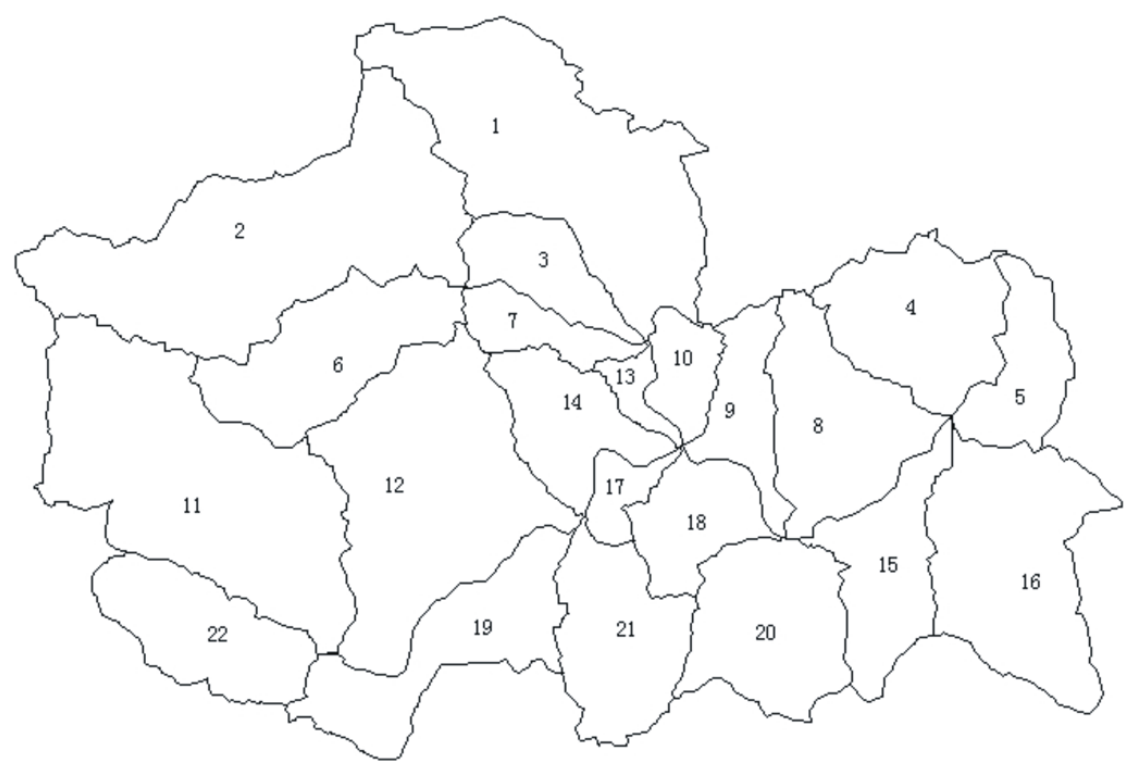

Figure 2. HRUs delineations for the Trent River basin.

Hydrographic networks were first generated from the DEM, and then were overlaid with landcover and soil maps to create HRUs. Each HRU was assumed to be homogeneous with respect to its soil, vegetative cover, slope, aspect, altitude, and precipitation distribution. Multiple sizes of HRUs $(22,71$, 118, and 225 HRUs) were tested to determine how HRU size affected the overall simulation efficiency. The model testing showed that it was most appropriate to use 22 HRUs for this watershed for modeling daily runoff (table 2 and fig. 2).

We parameterized the model by soil type for each HRU (table 1). The main parameters of the PRMS at the daily scale include vegetation density, soil depth of different soil zones, soil water capacity, and infiltration characteristics (table 3 ).
Evapotranspiration is a very important process in the model. We selected the Hamon method for predicting evapotranspiration using the results of $\mathrm{Lu}$ et al. (2006), which showed that the Hamon method works well for the research area. Because of the watershed's flat terrain, we assumed a uniform distribution in rainfall and air temperature across the basin.

Using a raster elevation data set (DEM), the ArcInfobased GIS Weasel creates a variety of products, most notably digital spatial data sets and text parameter files. The system has three major processing phases: setup, delineation, and parameterization. In the setup phase, a variety of topographic surfaces are derived from the user-supplied DEM. The delineation phase provides the Tool Panel to allow the user to de-

Table 3. Key parameters used by the PRMS model for the Trent River basin.

\begin{tabular}{|c|c|c|c|c|}
\hline Parameter & Description (units) & Default & Range & $\begin{array}{l}\text { Optimized } \\
\text { Values }\end{array}$ \\
\hline carea_max & Maximum possible area contributing to surface runoff (decimal) & 0.6 & $0-1$ & $0.3-1.0$ \\
\hline covden_sum & Summer vegetation cover density (decimal) & 0.5 & $0-1$ & $0.2-0.35$ \\
\hline covden win & Winter vegetation cover density (decimal) & 0.5 & $0-1$ & $0.1-0.35$ \\
\hline smidx $\overline{c o e f}$ & Coefficient in non-linear contributing area algorithm & $0.0001-1$ & 0.01 & $0.0014-0.0015$ \\
\hline smidx_exp & Exponent in non-linear contributing area algorithm & 0.3 & $0.2-0.8$ & 0.299 \\
\hline soil2gw_max & Maximum rate of soil water excess moving to groundwater (inches/day) & 0 & $0-5$ & $12.0-24.0$ \\
\hline soil_moist_init & Initial value of available water in a soil profile (inches) & 3 & $0-20$ & $0.6-2.0$ \\
\hline soil_moist_max & Maximum available water-holding capacity of the soil profile (inches) & 6 & $0-20$ & $0.8-4.0$ \\
\hline soil_rechr_init & Initial soil water for recharge zone (inches) & 1 & $0-10$ & $0.2-0.401$ \\
\hline soil_rechr_max & Maximum available water-holding capacity (inches) & 2 & $0-10$ & $0.4-0.8$ \\
\hline srain_intep & Summer rain interception storage capacity for the major vegetation type in the HRU & 0.1 & $0-5$ & $0.03-0.1$ \\
\hline ssr2gw_rate & Coefficient to route water from the subsurface to groundwater & 1 & $0-3$ & $0.2-0.8$ \\
\hline gwflow_coef & Groundwater routing coefficient (1/day) & 0.015 & $0-1$ & 0.06757 \\
\hline
\end{tabular}


lineate different kinds of geographic features, and it includes the tools that have been developed in support of the Precipitation Runoff Modeling System (PRMS) (Leavesley et al., 1983). The parameterization phase has an option to produce an additional file that is specifically formatted for use with the Modular Modeling System (Leavesley, 1994; www.brr.cr.usgs.gov/mms).

\section{Model Performance Evaluation}

Model performance at daily and monthly temporal scales was evaluated using the standard model efficiency $(E)$ (Nash and Sutcliffe, 1970) and relative error $(E r)$ for both the calibration and validation periods. The Nash-Sutcliffe method as presented below is widely used in hydrologic modeling. The $E$ value varies from negative infinity to 1.0 , with higher values indicating better agreement between simulated and observed values. $E$ is highly sensitive to estimation errors for high values (i.e., peak flow values).

$$
E=\frac{\sum_{1}^{N}\left(Q_{o i}-Q_{o}\right)^{2}-\sum_{1}^{N}\left(Q_{o i}-Q_{s i}\right)^{2}}{\sum_{1}^{N}\left(Q_{o i}-Q_{o}\right)^{2}}
$$

where

$E=$ model goodness-of-fit efficiency

$Q_{o \mathrm{i}}=$ observed streamflow for day or month $i$

$Q_{s i}=$ simulated streamflow for day or month $i$

$Q_{o}=$ mean observed daily or monthly streamflow

$N=$ number of samples.

Relative volume errors: $E_{r}=\frac{\Delta Q}{\bar{Q}} \times 100 \%$

where

$$
\begin{aligned}
& \Delta Q=\frac{1}{N} \sum_{i=1}^{N} \Delta Q_{i} \\
& \Delta Q_{i}=\left|X_{s i}-X_{o i}\right| \\
& \bar{Q}=\frac{1}{N} \sum_{i=1}^{N} Q_{s i}
\end{aligned}
$$

The hydrologic years (October-September) from 1993 to 2001 included both extremely dry and wet years and thus were designated as the model calibration period, while 1981-1990 was designated as the model validation period. Streamflow measurements during 1991 and 1992 were not available, so these two years were excluded from the analysis. The PRMS model was tested initially with default parameters that were generated directly from GIS Weasel. It was then modified by adjusting parameter values as described above, and other parameters were set by model optimization.

\section{Hydrologic Response to Climatic Perturbations and LONG-TERM IMPACTS OF CLIMATE AND LANDUSE CHANGES ON STREAMFLOW}

Although there have been great advances with GCMs over the past decade and hydrologists have confidence in their overall predictions, large uncertainties remain regarding future changes in climate for particular regions or basins. In fact, different GCMs have given different directions of changes in precipitation for the southeastern U.S., so hydro-
Table 4. Landuse compositions for seven hypothetical simulation scenarios developed for Trent River.

\begin{tabular}{lccccc}
\hline & $\begin{array}{c}\text { Forest } \\
(\%)\end{array}$ & $\begin{array}{c}\text { Crops and } \\
\text { Grassland } \\
(\%)\end{array}$ & $\begin{array}{c}\text { Urban } \\
\text { Land } \\
(\%)\end{array}$ & $\begin{array}{c}\text { Water } \\
(\%)\end{array}$ & $\begin{array}{c}\text { Total } \\
(\%)\end{array}$ \\
\hline Base line & 69.3 & 29.2 & 1.4 & 0.1 & 100 \\
Scenario 1 & 53.5 & 45.0 & 1.4 & 0.1 & 100 \\
Scenario 2 & 38.5 & 60.0 & 1.4 & 0.1 & 100 \\
Scenario 3 & 23.5 & 75.0 & 1.4 & 0.1 & 100 \\
Scenario 4 & 3.5 & 95.0 & 1.4 & 0.1 & 100 \\
Scenario 5 & 0 & 100.0 & 0.00 & 0.00 & 100 \\
Scenario 6 & 60.7 & 29.2 & 10.0 & 0.1 & 100 \\
Scenario 7 & 34.9 & 45.0 & 20.0 & 0.1 & 100 \\
\hline
\end{tabular}

logic perturbation studies are useful to explore the potential bounds of hydrologic responses for any one basin (Nash and Gleick, 1991). In this study, we examined a range of climate change cases that involve a $10 \%$ to $20 \%$ change in the amount of daily rainfall and $1.1^{\circ} \mathrm{C}$ to $2.8^{\circ} \mathrm{C}$ changes in air temperature from the measured baseline climate (1993-2001). These hypothetical changes were chosen using general projections by the GCMs for the study region (National Assessment Synthesis Team, 2000).

Analyses of the hydrologic response to uniform changes in climate provided some insight to the hydrologic response, but it did not consider temporal variability of the "change" in both precipitation and temperature nor the combined, cumulative effects of the climate. Thus, we applied the validated model to simulate streamflow patterns for the next 100 years using a climate time series generate from two GCM scenarios, CGC1 and HadCMSul2, representing "hot and dry" and "hot and wet" scenarios for the southeastern U.S., respectively. Both models have been widely used by climate and hydrologic research communities (McNulty et al., 1997; National Assessment Synthesis Team. 2000).

We developed seven hypothetical scenarios to examine streamflow responses to future landuse changes, represented by forest conversion to crops and grassland and urban use (table 4). These scenarios included increasing crop and grassland area from $33 \%$ to $45 \%, 60 \%, 75 \%, 95 \%$, and $100 \%$ of the total watershed area by decreasing forest area accordingly. For example, an increase of crop and grassland cover from $33 \%$ to $45 \%$ equaled a decrease of forest cover from approximately $77 \%$ to $55 \%$. In two other scenarios, urban land was increased from $1 \%$ to $10 \%$ and $20 \%$ of the total basin area by reducing forest land area.

\section{Results AND Discussion \\ Model Calibration and Validation at Daily ANd MonThly SCALES}

A total of 22 HRUs was used for model calibration and validation. Reasonable agreement between the measured and simulated runoff during the calibration period was achieved, with averaged $E$ values and relative error $(E r)$ values ranging from 0.58 and $56 \%$, respectively, for the daily scale to 0.79 and $38 \%$ for the monthly scale (table 2 ). The $E$ values averaged 0.49 for the validation period, ranging from -0.46 to 0.78 for the daily time scale, and averaged $0.58(-0.52$ to $0.96)$ for the monthly scale. Relative errors for the validation period were $63 \%$ and $46 \%$ for the daily and monthly time scale, respectively. 


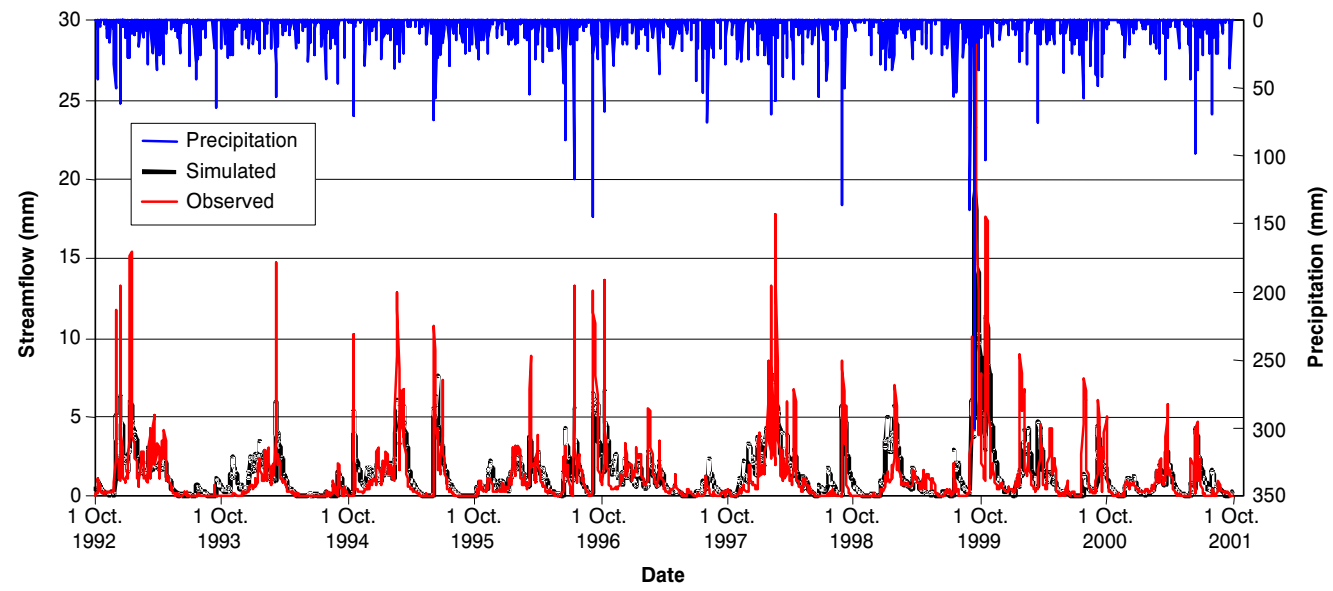

Figure 3. PRMS model calibration at the daily scale during 1993-2001.

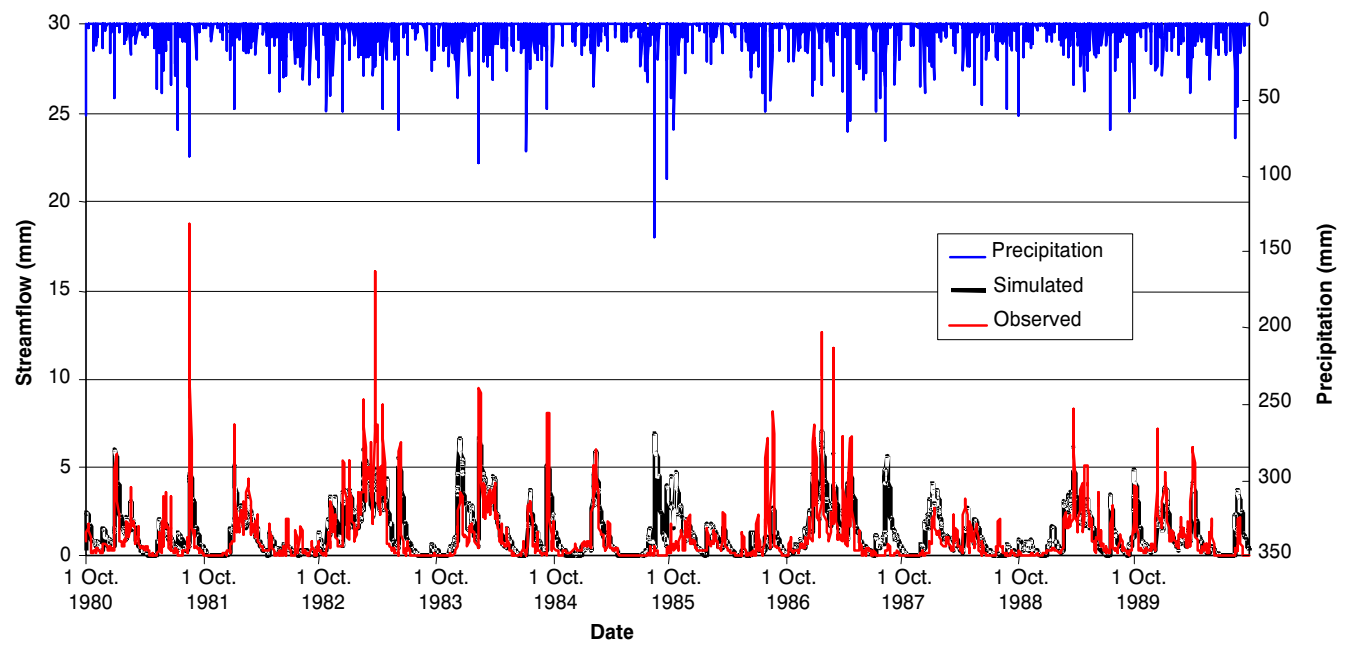

Figure 4. PRMS model validation at the daily scale during 1980-1991.

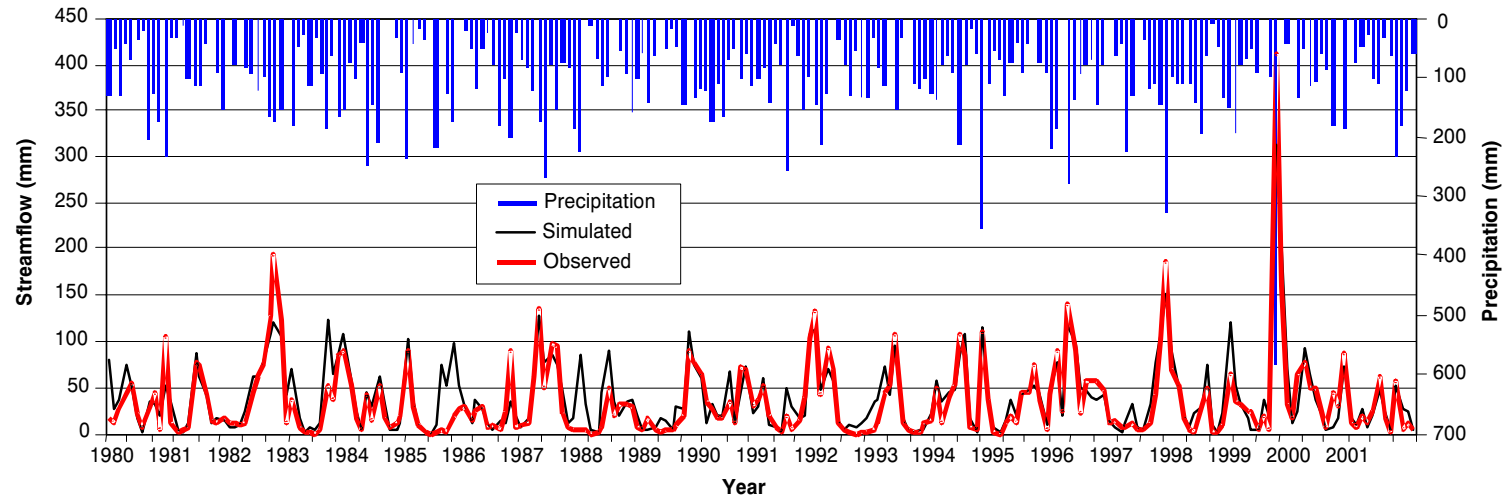

Figure 5. PRMS model calibration (1993-2001) and validation (1980-1991) at the monthly scale.

The model generally underestimated daily streamflow for large storm events occurring primarily during January and March when evapotranspiration was the lowest and the watershed was wettest (figs. 3 and 4). Hurricanes cause major flooding events in eastern North Carolina. For example, a 100-year flood event occurred during 14-16 September 1999 as a result of more than $330 \mathrm{~mm}$ of rain dropped by Hurricane Floyd. The soils had been saturated from Hurricane Dennis' pass on 4-5 September, which produced $140 \mathrm{~mm}$ rainfall. The model overestimated daily flow by $10 \mathrm{~mm}$ for the first day (14 Sept.) but underestimated it by 59 and $40 \mathrm{~mm}$ for the following two days, respectively (fig. 3). These results suggest that the model's daily time step was not sufficient to capture daily peak flows, perhaps due to stormflow routing problems. The model overestimated a few moderate daily flow events (fig. 4). The most obvious examples are the year 1985, where the $E$ had a negative value. The underestimation occurred for large storms or hurricanes immediately after a long drought 
period, mostly in the summer months, such as in the event of 19 August 1985, when a total of $140 \mathrm{~mm}$ rainfall fell. The model's insensitivity to large storm events may suggest that the watershed storage capacity was set too high and/or the evapotranspiration model overpredicted the depletion of soil moisture prior to the hurricane. Another reason for the poor performance of the PRMS model following a hurricane may be due to the uneven spatial distribution of precipitation during the storm. Local amounts of precipitation may vary greatly across the watershed. PRMS performed better at the monthly time step for both the calibration and validation periods (table 2; fig. 5). The model adequately estimated streamflow patterns and volumes at the monthly time step, suggesting model's strength in water balance calculation at large temporal scales.

The long-term (1981-2001) simulation suggested that approximately $878 \mathrm{~mm}$ or $70 \%$ of precipitation $(1258 \mathrm{~mm}$ ), was returned to the atmosphere as evapotranspiration, and the other $380 \mathrm{~mm}$ or $30 \%$ of precipitation became stream runoff. The annual streamflow runoff coefficient (streamflow/precipitation) varied greatly, ranging from $18.4 \%$ in 2001 to $39.2 \%$ in 1998 .

The averaged annual simulation errors ranged from -62 to $51 \mathrm{~mm}$, and relative error ranged from $-3.4 \%$ to $25.4 \%$. We did not find any correlations between simulation errors and either precipitation or measured runoff. However, it appears than the absolute simulation errors were higher during extreme climatic conditions, either too dry or too wet. We used the averaged simulation error to set bounds for future streamflow predictions.

\section{Potential Responses of Streamflow to Climate Change}

As the air temperature was increased or decreased by $1.11^{\circ} \mathrm{C}$ each day, water yield showed a decrease or increase of approximately $6 \%$ of the baseline values, with a variation of $3 \%$ to $11 \%$. Similarly, when temperature increased by $2.78^{\circ} \mathrm{C}$, water yield decreased by an average of $15 \%$ with a larger variation of $9 \%$ to $31 \%$ (fig. 6). The effects of air temperature on water yield are due to its effects on evapotranspiration (ET); the effects of precipitation on water yield are propagated through both ET and other water fluxes in the watershed. As expected, actual ET increases and water yield decreases with increase of temperature, and vice versa (fig. 6).
When temperature was increased by $1.11^{\circ} \mathrm{C}$, the average ET increase was $2.7 \%$, while the water yield decreased by $5.7 \%$ (fig. 6). When temperature was increased by $2.8^{\circ} \mathrm{C}$, ET and water yield changes were more than doubled, with increases and decreases of $6.2 \%$ and $13.9 \%$, respectively. Compared to streamflow response, the relatively smaller ET response was partially due to its higher absolute magnitude at the baseline of about $900 \mathrm{~mm} /$ year. Baseline streamflow was approximately $300 \mathrm{~mm} /$ year.

Streamflow was found to be very sensitive to the prescribed precipitation changes (fig. 6). When compared to the baseline, a $10 \%$ change in precipitation resulted in a mean change of $20 \%$ in annul streamflow, ranging from $2 \%$ to $55 \%$ over the 10-year simulation period (1992-2001). A $20 \%$ change in precipitation resulted in a mean streamflow change of $45 \%$, ranging from $31 \%$ to $60 \%$ (fig. 6). A strong nonlinear response was observed, suggesting that the Trent River basin may be more responsive to large increases in precipitation, such as those seen with the $20 \%$ scenario. A small change in precipitation may have large effects on streamflow between years, presumably due to the large variations in annual baseline precipitation and streamflow. In contrast, a large increase or decrease in precipitation would certainly aggravate the hydrologic extremes of floods or droughts.

Simulation results showed that a $10 \%$ increase in precipitation would result in an average increase in ET of $4 \%$ and an increase in streamflow of $23 \%$. When the change in precipitation was doubled (i.e., $20 \%$ increase), ET and streamflow were roughly doubled as well. These results suggest that, compared to streamflow, ET in the Trent River basin was rather stable under all of the tested climate change scenarios. Small changes in ET had large effects on streamflow for the study basin, where ET flux (mm/year) is much larger than streamflow (mm/year) in magnitude. The simulations also suggest that streamflow in the Trent River basin was less responsive to projected air temperature change than changes in precipitation, as prescribed in this study. However, this simulation exercise did not consider potential biological changes to plant structure, biomass, species composition, and $\mathrm{CO}_{2}$ effects on plant transpiration. Atmospheric chemistry may have profound effects on plant transpiration and streamflow at multiple scales (Hanson et al., 2005; McLaughlin et al., 2007).

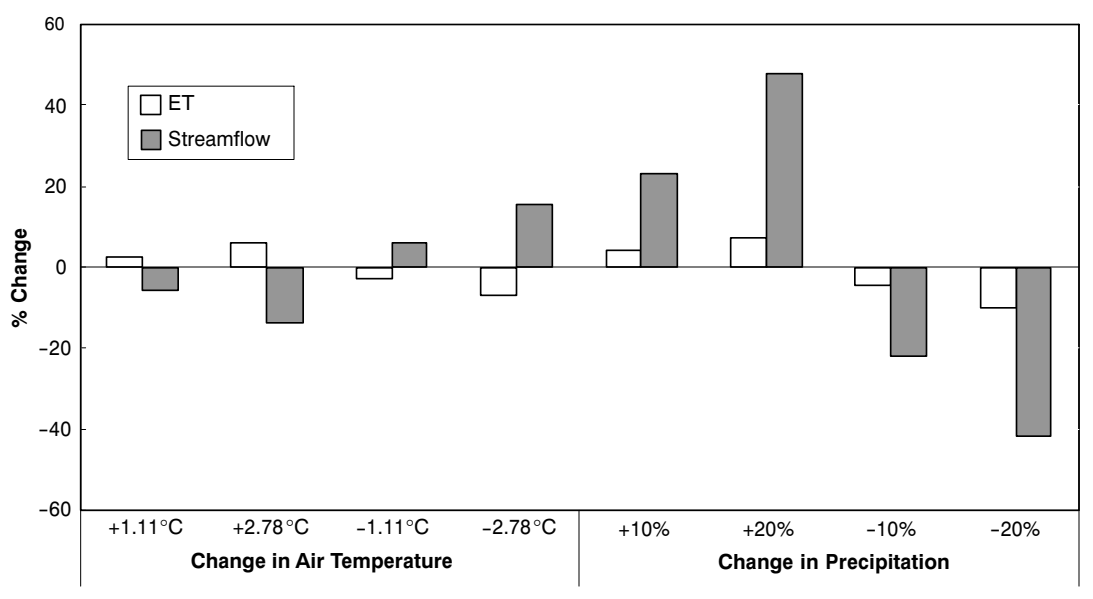

Figure 6. Response of streamflow and evapotranspiration to potential precipitation and air temperature changes in the Trent River during $1992-2001$. 


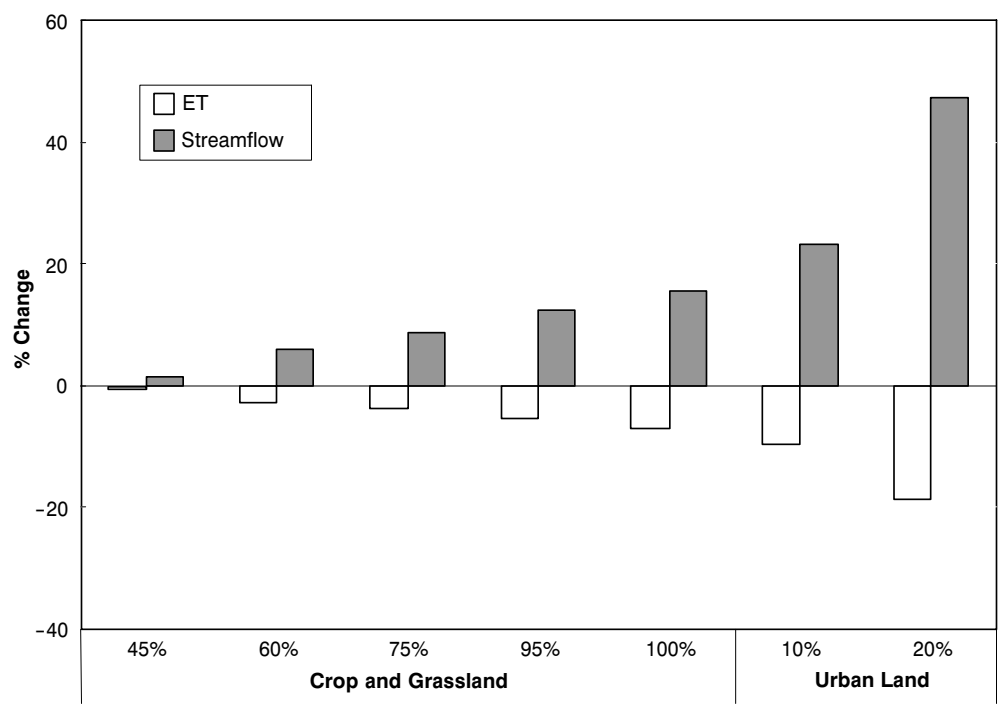

Figure 7. Responses of streamflow and evapotranspiration to potential landuse change in the Trent River during 1992-2001.
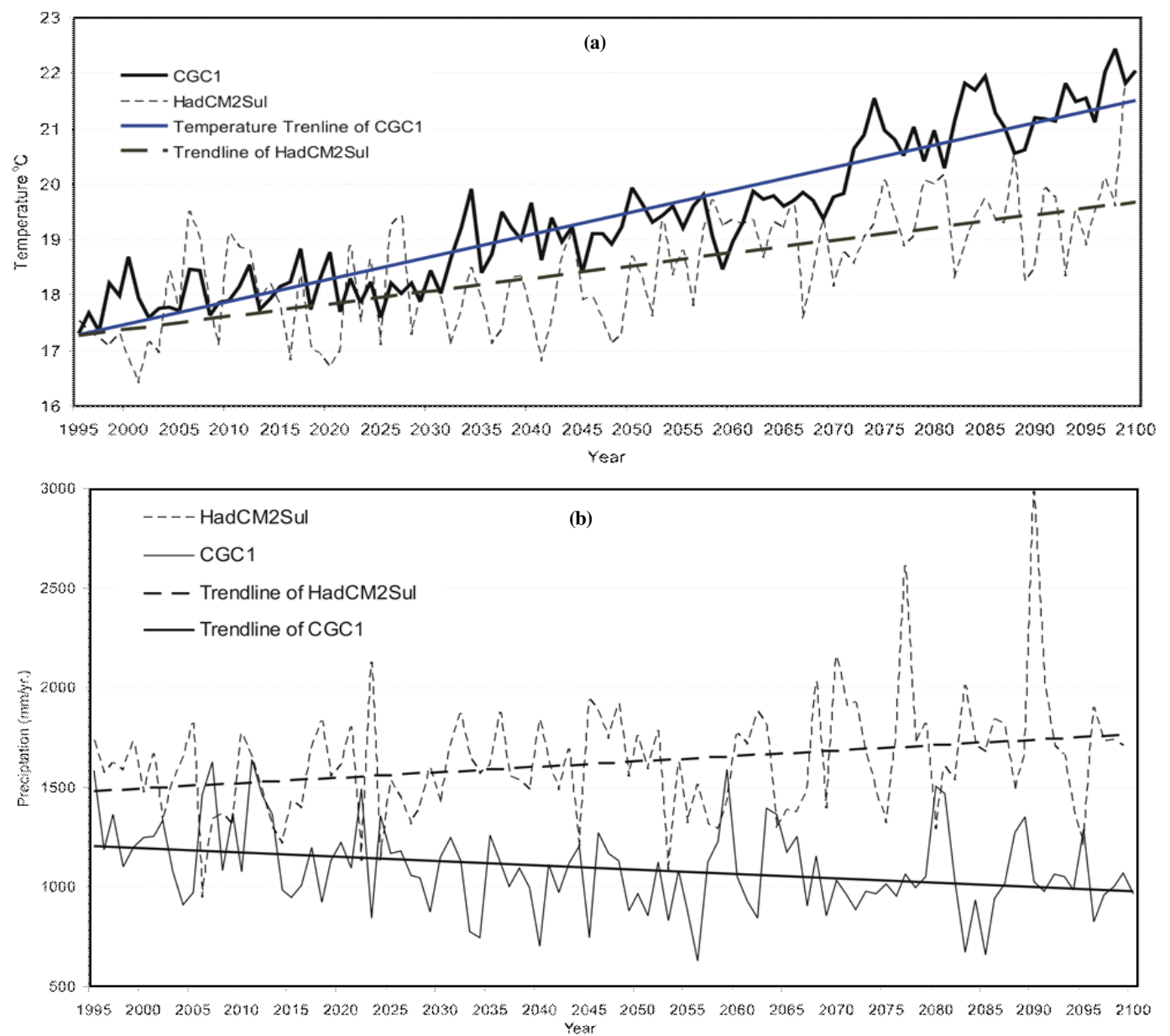

Figure 8. Projected climate change by two GCMs, HadCMSul2 and CGC1, for the Trent River: (a) annual air temperature and (b) annual total precipitation.

Streamflow Response to Potential Landuse Change

Streamflow showed a variable increase when forests were converted to cropland and urban uses (fig. 7). Evapotranspiration was reduced with the increases in crop and grassland proportions because agricultural crops and grasses consume less water than forests; this general trend has been well reported in the literature. For example, worldwide em- pirical studies suggest that deforestation can increase water yield proportionally to the basal area removed (Andreassian, 2004). Our simulation showed that a complete conversion from forests to crops and grasses resulted in a $7 \%$ decreased in ET (from 876 to $817 \mathrm{~mm} /$ year). This was equivalent to an increase in water yield of $59 \mathrm{~mm} /$ year, or $14 \%$ from the base line (426 mm/year). Increasing urban land area from $1 \%$ to 
$20 \%$ caused a decrease in ET of $18.6 \%(163 \mathrm{~mm} /$ year $)$ and an increase of water yield of $38 \%$ (fig. 7). Overall, the impacts of landuse change on the absolute values of ET and water yield were in the lower range reported in the literature for upland conditions but were comparable to findings from lowland regions (Sun et al., 2000; Amatya et al., 2006). Small watershed experiments in the Appalachian Mountains of western North Carolina found that forest clearcutting normally caused as much as $400 \mathrm{~mm} / \mathrm{year}$ of streamflow or $50 \%$ increase of runoff (Swank et al., 2001). Streamflow response from lowland areas that are dominated by wetlands was generally lower, approximately $150 \mathrm{~mm} /$ year (Sun et al., 2004).

\section{Hydrologic Impacts of Two Transient Climate Change Scenarios Over the Next 100 Years}

The two GCMs predicted different 21st century climates for the study region (fig. 8). On average, over the study region, the U.K. HadCMSul2 model projected a much wetter climate than the Canadian CGC1 model, while the CGC1 model projected a greater increase in temperature than the HadCMSul2 model (fig. 8). We used averaged historic data from 1896 to 1994 as a baseline to examine streamflow responses to these climate change scenarios.
Annual streamflow and ET values showed an increasing trend under the HadCMSul2 scenario. Changes in water yield varied from $-34 \%$ to $238 \%$, and changes in ET varied from $-21 \%$ to $37 \%$. The increasing trend was largely due to the increase in precipitation associated with the HadCMSul2 scenario (fig. 9). In contrast, under the CGC1 scenario, both streamflow and ET showed a decreasing trend (fig. 10). Compared to baseline conditions, annual streamflow varied from $-93 \%$ to $45 \%$, and ET varied from $-37 \%$ to $21 \%$ of baseline. The decreasing trends in both ET and streamflow were due to a decrease in precipitation (fig. 10). Increase in air temperature did not result in an increase of water loss to the atmosphere due to a severe decrease in precipitation that created dry soil conditions and reduction of plant canopy interception. In such a case, soil water might have exerted limitations on ET. Similar to findings from the climate change sensitivity analysis, this 99 -year simulation highlighted the dominant influences of precipitation on streamflow for the study watershed. The effects of increased air temperature appeared to be canceled out by the changes in precipitation for both scenarios.

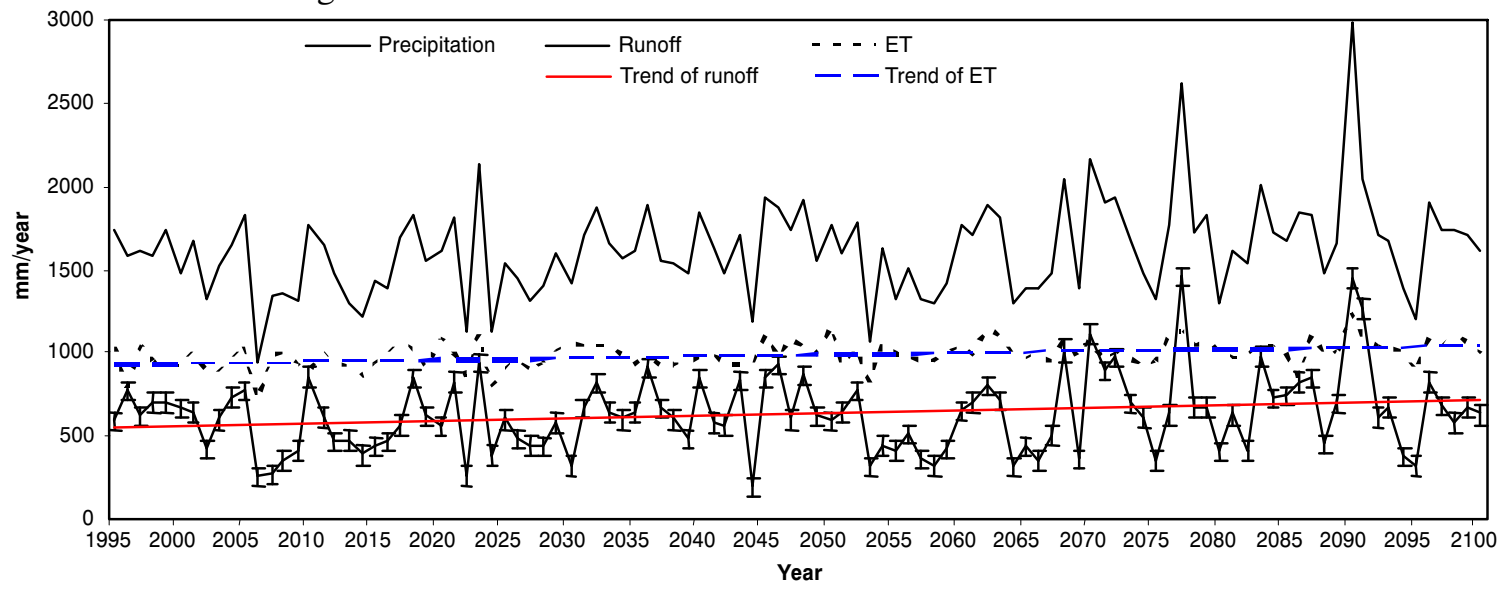

Figure 9. Predicted responses of annual streamflow and evapotranspiration to the HadCMSul2 climate change scenario (1995-2099).

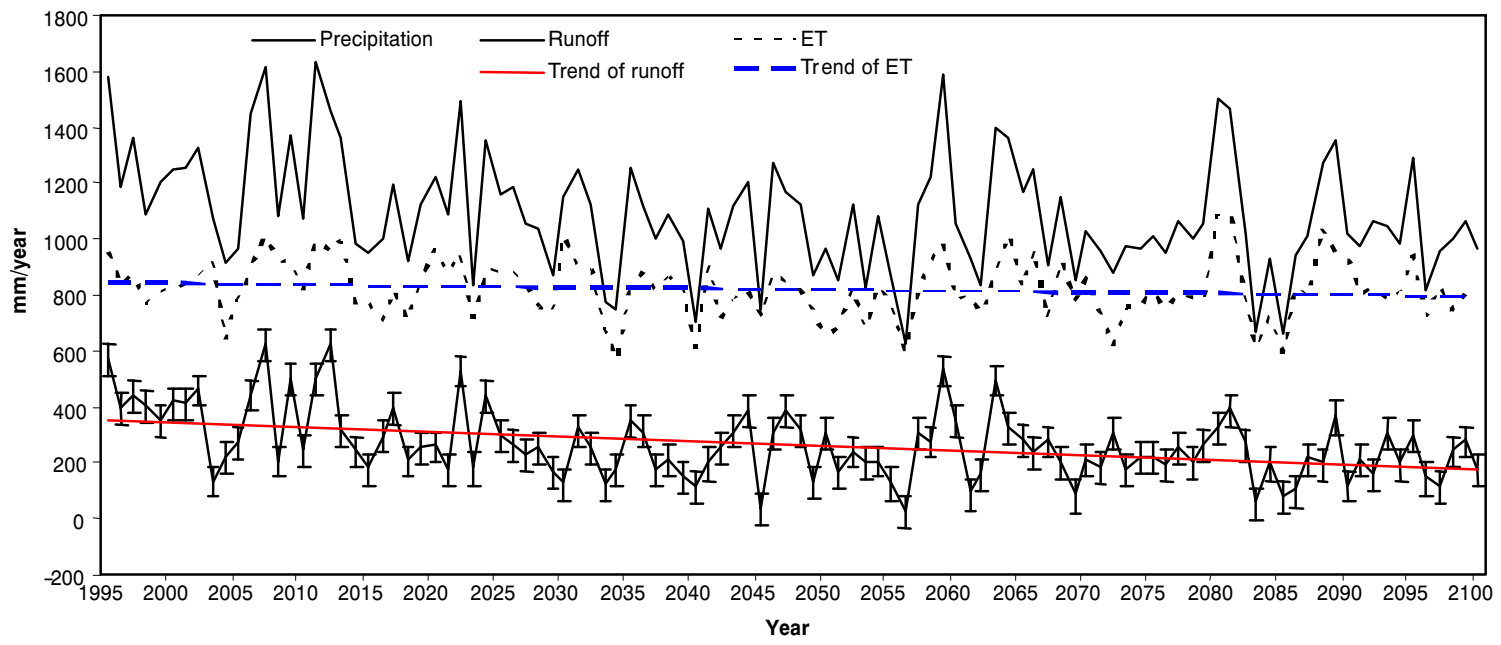

Figure 10. Predicted responses of annual streamflow and evapotranspiration to the CGC1 climate change scenario (1995-2100). 


\section{Conclusions}

The PRMS model performed reasonably well in simulating monthly streamflow in the Trent River basin, with an average model-fit efficiency of 0.85 for a 20 -year period. However, the model should not be used to predict daily flow with daily rainfall inputs. To predict peak flows or daily flows, other modules of the PRMS model may be employed to best represent channel flow routings.

Given the prescribed bounds of possible climate change of $\pm 10 \%$ to $20 \%$ in precipitation and $\pm 1.11^{\circ} \mathrm{C}$ to $2.78^{\circ} \mathrm{C}$ in air temperature, the streamflow of the Trent River was found to be more sensitive to changes in precipitation than to changes in air temperature. Evapotranspiration was a large component of the annual water balance ( $>70 \%$ of precipitation), so its relative change was always smaller when compared to streamflow because of its magnitude.

Our basin-scale simulation study confirmed that moderate urbanization, simulated as an increase of urban area from $1 \%$ to $10 \%$, might increase streamflow greatly $(>20 \%)$. In contrast, conversion from a forest-dominated watershed $(70 \%$ forest, $30 \%$ grassland and cropland) to a grassland or cropdominated watershed (75\% grassland and cropland) might not cause a large increase in streamflow $(<10 \%)$. Increased runoff from land conversions from forests to other landuses may pose a water quality threat to river systems due to increased soil erosion. Simulated streamflow responses to climate change scenarios of the HadCMSul2 and CGC1 GCMs suggest that precipitation may overwhelm the effects of increased air temperature alone. Increase of precipitation frequency and intensity will likely affect streamflow response as well. This is one important aspect of the hydrologic changes for the coastal region, where the hydrologic processes are dominated by the "saturation excess" flow generation mechanisms (Sun et al., 2001).

Similar to other impact studies (Jha et al., 2006), unfortunately, the two GCMs predicted two different future precipitation patterns for the study region. As pointed out by Huntingford et al. (2006), there is a strong need to improve GCM prediction accuracy at the regional scale and make the data available to hydrologists at scales useful for hydrologic impact modeling. Reducing the uncertainty of climate prediction at the watershed scale is greatly needed for future impact assessments. In addition, future models should include plant water use feedbacks to increases in atmospheric $\mathrm{CO}_{2}$ and other pollutants (i.e., ozone) (McLaughlin et al., 2007) and associated physiological changes of plants (Hanson et al., 2005).

Climate change is likely to cause significant change to the hydrologic extremes of river basins in the coastal plain region regardless of landuse changes (Sun et al., 2008). Urbanization and associated landuse changes are expected to affect the quality of water, which is in increasing demand as the human population continues to rise in the coastal regions that are experiencing sea level rise and groundwater overuse. Water resource managers should design flexible facilities to respond to the hydrologic extremes caused by climate change and increased human demand.

\section{ACKNOWLEDGEMENTS}

This study was supported by China Scholarship Council for Shi Qi's postdoctoral study at North Carolina State University. Partial support was provided by China National Natu- ral Science Foundation (Grant No. 30571486) and the USDA Forest Service Southern Global Change Program. The authors are grateful for the insights from two anonymous reviewers and the ASABE Associate Editor, which greatly improved the original manuscript.

\section{REFERENCES}

Amatya, D. M., R. W. Skaggs, and J. D. Gregory. 1997. Evaluation of a watershed-scale forest hydrologic model. J. Agric. Water Mgmt. 32(2): 239-258.

Amatya, D. M., G. Sun, R. W. Skaggs, G. M. Chescheir, and J. E. Nettles. 2006. Hydrologic effects of global climate change on a large drained pine forest. In Proc. Intl. Conf. on Hydrology and Management of Forested Wetlands, 383-394. St. Joseph, Mich.: ASABE.

Anderson, J. R., E. E. Hardy, J. T. Roach, and R. E. Witmer. 1976. A land use and cover classification system for use with remote sensing data. USGS Prof. Paper No. 964: 28. Washington, D.C.: U.S. Geological Survey.

Andersen, J., J. C. Refsgaard, and K. H. Jensen. 2001. Distributed hydrological modeling of the Senegal River basin: Model construction and validation. J. Hydrol. 247(3-4): 200-214.

Andreassian, V. 2004. Water and forests: From historical controversy to scientific debate. J. Hydrol. 291(1-2): 1-27.

Arnold, J. G., and N. Fohrer. 2005. SWAT2000: Current capacities and research opportunities in applied watershed modeling. Hydrol. Proc. 19(3): 563-572.

Arnold, J. G., R. Srinivasan, R. S. Muttiah, and J. R. Williams. 1998. Large-area hydrologic modeling and assessment: Part 1. Model development. JAWRA 34(1): 73-89.

Barlage, M. J., P. L. Richards, P. J. Sousounis, and A. J. Brenner. 2002. Impacts of climate change and land use change on runoff from a Great Lakes watershed. J. Great Lakes Res. 28(4): 568-582.

Borah, D. K., and M. Bera. 2003. Watershed-scale hydrologic and non-point source pollution models: Review of mathematical basis. Trans. ASAE 46(6): 1553-1566.

Bosch, D. D, and J. M. Sheridan. 2006. Long-term hydrologic trends on the Little River experimental watershed. In Proc. 2nd Interagency Conf. on Research in the Watersheds. St. Joseph, Mich.: ASABE.

Brian, H. H, M. Callaway, J. Smith, and P. Karshen. 2004. Climatic change and U.S. water resources: From modeled watershed impacts to national estimates. JAWRA 40(1): 129-148.

Brown, A. E., L. Zhang, T. A. McMahon, A. W. Westen, and R. A. Vertessy. 2005. A review of paired catchment studies for determining changes in water yield resulting from alterations in vegetation. J. Hydrol. 310: 28-61.

Calder, I. R., R. L. Hall, H. G. Bastable, H. M. Gunston, O. Shela, A. Chirwa, and R. Kafundu. 1995. The impact of land use change on water resources in sub-Saharan Africa: A modeling study of Lake Malawi. J. Hydrol. 170: 123-135.

Chang, M. 2002. Forest Hydrology: An Introduction to Water and Forest. New York, N.Y.: CRC Press.

Hanson, P. J., S. D. Wullschleger, R. J. Norby, T. J. Tschaplinski, and C. A. Gunderson. 2005. Importance of changing $\mathrm{CO}_{2}$, temperature, precipitation, and ozone on carbon and water cycles of an upland oak forest: Incorporating experimental results into model simulations. Global Change Biol. 11(9): 1402-1423.

Hay, L. E., G. H. Leavesley, M. P. Clark, S. L. Markstrom, R. J. Viger, and M. Umemoto. 2006. Stepwise, multiple objective calibration of a hydrologic model for a snowmelt dominated basin. JAWRA 42(4): 877-890.

Huntingford, C., J. Gash, and A. M. Giacomello. 2006. Climate change and hydrology: Next steps for climate. Hydrol. Proc. 20(9): 2085-2087.

Jackson, C. R., G. Sun, D. M. Amatya, W. T. Swank, M. Riedel, J. Patric, T. Williams, J. M. Vose, C. C. Trettin, W. M. Aust, S. 
Beasely, H. Williston, and G. Ice. 2004. Fifty years of forest hydrology research in the southeast: Some lessons learned. In $A$ Century of Forest and Wildland Watershed Lessons, 33-112. J. Stednick and G. Ice, eds. Bethesda, Md.: Society of American Foresters.

Jha, M., J. G. Arnold, P. W. Grassman, F. Giorgi, and R. R. Gu. 2006. Climate change sensitivity assessment on upper Mississippi basin streamflows using SWAT. JAWRA 42(4): 997-1016.

Kittel, T. G. F., J. A. Royle, C. Daly, N. A. Rosenbloom, W. P. Gibson, H. H. Fisher, D. S. Schimel, L. M. Berliner, and VEMAP2 Participants. 1997. A gridded historical (1895-1993) bioclimate dataset for the conterminous United States. In Proc. 10th Conf. on Applied Climatology, 219-222. Boston, Mass.: American Meteorological Society.

Leavesley, G. H. 1994. Modeling the effects of climate change on water resources: A review. Climatic Change 28(1-2): 159-177.

Leavesley, G. H., R. W. Lichty, B. M. Troutman, and L. G. Saindon. 1983. Precipitation-runoff modeling system: User's manual. USGS Water Resources Investigations Report 83-4238. Denver, Colo.: U.S. Geological Survey.

Leavesley, G. H., S. L. Markstrom, P. J. Restrepo, and R. J. Viger. 2002. A modular approach to addressing models design, scale, and parameter estimation issues in distributed hydrological modeling. Hydrol. Proc. 16(2): 173-187.

Legesse, D., C. Vallet-Coulomb, and F. Gasse. 2003. Hydrological response of a catchment to climate and land use change in tropical Africa: Case study south central Ethiopia. J. Hydrol. 275(1-2): 67-85.

Liang, Y., S. R. Durrans, and T. Lightsey. 2002. A revised version of PnET-II to simulate the hydrologic cycle in southeastern forested areas. JAWRA 38(1): 79-89.

Lorup, J. K., J. C. Refsgaard, and D. Mazvimavi. 1998. Assessing the effect of land use change on catchment runoff by combined use of statistical tests and hydrological modeling: Case studies from Zimbabwe. J. Hydrol. 205(3-4): 147-163.

Lu, J., G. Sun, S. M. Amatya, S. V. Harder, and S. G. McNulty. 2006. Understanding the hydrologic response of a coastal plain watershed to forest management and climate change in South Carolina, USA. In Proc. Intl. Conf. on Hydrology and Management of Forested Wetlands, 231-239. St. Joseph, Mich.: ASABE.

McLaughlin, S. B., S. D. Wullschleger, G. Sun, and M. Nosal. 2007. Interactive effects of ozone and climate on southern Appalachian forests in the USA: II. Effects on water use, soil moisture content, and streamflow. New Phytol. 174(1): 125-136.

McNulty, S. G, J. M. Vose, and W. T. Swank. 1997. Regional hydrologic response of loblolly pine to air temperature and precipitation changes. JAWRA 33(5): 1011-1022.

Nash, J. E., and J. V. Sutcliffe. 1970. River flow forecasting through conceptual models: Part 1. A discussion of principles. J. Hydrol. 10(3): 282-290.

Nash, L., and P. H. Gleick. 1991. Sensitivity of streamflow in the Colorado basin to climate change. J. Hydrol. 125(3-4): 221-241.

National Assessment Synthesis Team. 2000. Climate change impacts on the United States: The potential consequences of climate variability and change. Washington D.C.: U.S. Global Change Research Program.

NPA Data Services, Inc. 1999. Economic Databases: Mid-range Growth Projections 1967-2050. Arlington, Va.: Regional Economic Projections Series.

Postel, S. L., G. C. Daily, and P. R. Ehrlich. 1996. Human appropriation of renewable fresh water. Science 271(5250): 785-788.

Refsgaard, J. C. 1987. A methodology for distinguishing between the effects of human influence and climate variability on the hydrological cycle. In The Influence of Climate Change and Climatic Variability on the Hydrologic Regime and Water Resources, 557-570. IAHS Publication 168. Oxfordshire, U.K.: IAHS Press.
Rose, S., and N. E. Peters. 2001. Effects of urbanization on streamflow in the Atlanta area (Georgia, USA): A comparative hydrological approach. Hydrol. Proc. 15(8): 1441-1457.

Rosenberg, N. J., D. J. Epstien, D. Wang, L. Vail, R. Srinivasan, and J. G. Arnold. 1999. Possible impacts of global warming on the hydrology of the Ogallala aquifer region. Climatic Change 42(4): 677-692.

Rosenberg, N. J., R. A. Brown, R. C. Izaurralde, and A. M. Thomson. 2003. Integrated assessment of Hadley Centre (HadCM2) climate change prediction on agricultural productivity and irrigation water supply in the conterminous United States I: Climate change scenarios and impacts on irrigation water supply simulated with HUMUS model. Agric. Forest Meteorol. 117(1-2): 73-96.

Skaggs, R. W., D. M. Amatya, G. M. Chescheir, C. D. Blanton, and J. W. Gilliam. 2006. Effects of drainage and management practices on hydrology of pine plantation. In Proc. Intl. Conf. on Hydrology and Management of Forested Wetlands, 3-14. St. Joseph, Mich.: ASABE.

Stone, M., R. Hotchkiss, C. Hubbard, T. Fontaine, L. Mearns, and J. Arnold. 2001. Impacts of climate change on Missouri River basin water yield. JAWRA 37(5): 1119-1128.

Sun, G., D. M. Amatya, S. G. McNulty, R. W. Skaggs, and J. H. Hughes. 2000. Climate change impacts on the hydrology and productivity of a pine plantation. JAWRA 36(2): 367-374.

Sun, G., S. G. McNulty, J. P. Shepard, D. M. Amatya, H. Riekerk, N. B. Comerford, R. W. Skaggs, and L. Swift, Jr. 2001. Effects of timber management on wetland hydrology in the southern United States. Forest Ecol. Mgmt. 143: 227-236.

Sun, G., M. Riedel, R. Jackson, R. Kolka, D. Amatya, and J. Shepard. 2004. Chapter 3: Influences of management of Southern forests on water quantity and quality. In Southern Forest Sciences: Past, Current, and Future, 394. Gen. Tech. Rep/ SRS-75. H. M. Rauscher and K. Johnsen, eds. Ashville, N.C.: U.S. Forest Service, Southern Research Station.

Sun, G., S. G. McNulty, J. A. Moore Myers, and E. C. Cohen. 2008. Impacts of multiple stresses on water demand and supply across the southeastern United States. JAWRA 44(6): 1441-1457.

Swank, W. T., J. M. Vose, and K. J. Elliott. 2001. Long-term hydrological and water quality responses following commercial clearcutting of mixed hardwoods on a southern Appalachian catchment. Forest Ecol. Mgmt. 143: 163-178.

Trimble, S. W., and F. H. Weirich. 1987. Reforestation reduces streamflow in the southeastern United States. J. Soil Water Cons. 42(4): 274-276.

USDA. 1992. Forest land distribution data for the United States. Starkville, Miss.: U.S. Forest Service, SouthernForest Experiment Station. Available at: www.epa.gov/docs/grd/forest_ inventory/. Accessed 15 September 2006.

USDA. 1994. U.S. General Soil Map (STATSGO). Washington, D.C.: USDA Natural Resources Conservation Service. Available at: http://soildatamart.nrcs.usda.gov. Accessed 20 October 2006.

Viger, R. J., S. L. Markstrom, and G. H. Leavesley. 1998. Chapter 7: The GIS Weasel: An interface for treatment of spatial information used in watershed modeling and water resource management. In Proc. 1st Federal Interagency Hydrologic Modeling Conf., II: 73-80. Washington, D.C.: Interagency Advisory Committee on Water Data.

Wear, D. N., and J. G. Greis. 2002. Southern forest resources assessment. Gen. Tech. Rep. SRS-53. Asheville, N.C.: U.S. Forest Service, Southern Research Station.

Wolock, D. M., and G. J. McCabe. 1999. Estimates of runoff using water balance and atmospheric general circulation models. JAWRA 35(6): 1341-1350.

$\mathrm{Xu}, \mathrm{C} .2000$. Climate change and hydrological models: A review of existing gaps and recent research developments. Water Resour. Mgmt. 13(5): 369-382. 
